\title{
Imperial Edict Monument: Hui Ethnic Group in the Qing Dynasty - Expression and Practice of Dynasty Identity
}

\author{
Yalin Chai \\ Center For studies of Ethnic Minorities in Northwest China of Lanzhou University Gansu, Lanzhou \\ 730000, China
}

Keywords: Qing Dynasty, Hui ethnic group, Identity.

\begin{abstract}
In the historical process of the formation and development of Hui nationality, state political power was always involved, which made Hui's ancestors' ethnic identity and dynasty identity share some conjugacy both in time and in space. Since there was a coriaceous interaction between the Hui's ethnic identity and dynasty identity, we were able to characterize this relationship in the form of ethnicity-dynasty identity. The imperial edict monument and emperor tablet in Masjid become a symbol and metaphor indicating the tight relation between Hui's ethnic identity and dynasty identity in Qing dynasty.
\end{abstract}

\section{Part 1}

In the long history of the formation of Hui nationality, the generation of ethnic identity always accompanied by the construction of national identity, in most historical contexts, the Hui's ethnic identity and national identity were all highlighted at the same time, and there was a close relationship, interaction and associated relation between the two identities. It could be considered that, in terms of external factors, the Hui nationality was finally been put into the framework of the Chinese ethnic community, and its national identity to China and self-identity as Chinese were established, all above can be attributed to the political governance of imperial power or state power of all dynasties in history. On the one hand, the Hui people, which was originally existed in Chinese society as a foreign ethnic group, was incorporated into the "caste system" of Yuan dynasty. After the completion of household registration as the people of Yuan dynasty, the Hui experienced the "enforced chinesization" in Ming dynasty" and "restructuring and reconstruction” in the Qing dynasty, until a Islamic "sinitic Muslim" whose belief was chinalized to a certain extent was formed, and then participated in the kingship and modern politics, ultimately formed the Chinese "Hui ethnic group" the Hui nationality. This process was exactly the results of all kinds of governance which was often conducted by each dynasty in ancient China in the form of imperial politics. It can be said that these political governance was the most fundamental external cause for the belonging consciousness made by the Hui community which regarded themselves as "Chinese" and would not be separated from "China". On the other hand, those foreign Muslim ethnic groups that came to China one thousand years ago and had nothing to do with Chinese traditional culture were governed by the strong Chinese civilization and imperial power in history, making them have to face the crisis of "disappear" or "subsistence" of their ethnic group.

This paper selected the Qing dynasty from the five dynasties including Tang, Song, Yuan, Ming, as well as Qing, cast sight on the ethnic identity and dynasty (state) identity of the Hui ethnic group in Qing dynasty, and conducted investigation on the correlation and resonance symbiotic phenomenon between the two identities, the reason to do so lied in: first of all, the Qing dynasty was not only the last feudal dynasty in Chinese history, but also the period of reaching the peak of perfection when autocratic monarchy further penetrated into the deeper society and was about to complete the national comprehensive control of the community at the grassroots level, which clearly reflected the interaction between the state power of the Qing dynasty and the Hui nationality. Secondly, in the period of the Republic of China or even in contemporary era, there appeared a strong interaction and 
mutualistic symbiosis between the ethnic identity and national identity of the Hui nationality. Although the political reality and political discourse delivered to the Hui completely changed, if trace to its source, however, we can find the original structure in the "ethnic - dynasty identity" of the Hui nationality in Qing Dynasty.

\section{Part 2}

In the Qing Dynasty, the government strengthened the regulation and control of the Hui nationality in many aspects, such as politics, economy, culture and so on, which made the Hui get the imperial asylum to a certain extent while also felt external pressure from the government and the society; at the same time, when surrounded by mainstream culture, the Hui also tried to win and expand the social and cultural environment in which it live through a variety of ways, and created favorable conditions for their own survival and continuity, though this attempt often began with the force of arms and ended in tragedy. It was in this historical context that many mosques in Qing Dynasty had monuments that engraved with the imperial edict, which demonstrated an intriguing phenomenon.

In 1724, namely the $2^{\text {nd }}$ year of Yong Zheng administration, the Shandong governor named Chen Shiguan reported to the Yong Zheng emperor, hoping to persuade the emperor to take tough measures to crack down on the Hui people and Islam so as to benefit local governance. After scrutinizing Chen Shiguan's report, we found that he took the Confucianism-oriented Chinese traditional culture as the criterion and used it to examine and criticize the Hui and its religious cultural characteristics because of its belief in Islam. In Chen Shiguan's point, the inherent cultural connotation of the Hui such as diet, funeral as well as festival were nothing but "all sorts of false accusation and false incrimination, completely ridiculous”, so he showed no understanding and respect about it. Let alone the Hui people, and even the Hui officials didn't have the freedom to believe in Islam because Chen Shiguan advised the emperor to force them " leave the Islam ".

After reading the said memorial to the throne, Yong Zheng emperor thought that the content of what was said by Chen Shiguan was too exaggerated and there were some problems in his way of coping with it, Yong Zheng pointed out that such things could be ignored, otherwise, on the contrary, it would affect the governance on society and people. As a minister, Chen Shiguan dared not forget Yong Zheng emperor's imperial edict. However, since Chen Shiguan was a traditional intellectual of Chinese feudal dynasty that was deeply influenced by the thought of "write letters or articles with the same characters, the distance between the two wheels of the carriage must be equal, achieve a unified world ", when facing the "embracer of foreign culture" that was different from the mainstream culture, he did not show a all-inclusive multiculturalism attitude. Therefore, five years later, in 1729, namely the $7^{\text {th }}$ year of Yong Zheng administration, Chen Shiguan once again submitted memorial to the throne to completely prohibit the Islam.

Chen Shiguan's deep discrimination against the Hui and Islam and resolute attitude to conduct suppression was by no means unique in court officials in the early Qing dynasty. Shortly prior to Chen Shiguan's second memorial to the throne, Yue Zhongqi, the governor of Shaanxi province, also expressed similar views and attitudes in his memorial to emperor Yong Zheng. Therefore, we can easily imagine that the Hui people lived at that time might be able to clearly feel all sorts of pressure from outside society and the mainstream culture, what's more, their survival and livelihood may also begin to face threat. Since the memorials which illustrated local leading officials' requirements to ban Islam and control the Hui came in succession, emperor Yong Zheng realized that the problem should be universal in the whole country, so, in April of the same year, he announced again the imperial edict to express his attitude and understanding towards Islam and the Hui people. Emperor Yong Zheng, as a king, asked local officials and the Hui people to adjust and strictly regulate their code of conduct. The decree issued by emperor Yong Zheng was engraved on stone by some Mosques, such as the monument engraving the imperial edict above in the Mosque on Huashi street, outside Beijing's Chongwenmen, which is protected by a pavilion housing the monument. 
Usually, local officials was only focused on the governance of all kinds of affairs in his own area, "not aim at success, but free from faults" was an important political goal that these officials kept seeking so as to ensure a smooth career without a hitch, therefore, they were often afraid of the advent of factors that would affect social stability and were easy to induce public security incidents in the area under their jurisdiction. However, the emperor was governing the whole country which had extensive territory, so, within the territory under the imperial rule, he must accept the existence of huge regional differences and ethnic differences. As a result, how to make all ethnic groups of different beliefs, different languages, different cultures, and different physical characteristics live on the same piece of land in peace, concord and harmony became a difficult examination to test the emperor's ruling ability and ruling wisdom. Emperor Yong Zheng selected the same way as that taken by wise kings in Chinese history, namely enlightening the world with noble virtues, actually, he took the principle of multiculturalism to treat different groups, "maintain their religious belief while not force them to change their customs, unify the government decree in ruler's hands but not change their traditional mode of production, lifestyle and customs", then there formed the basic governance mode of the dynasty. Therefore, the imperial emperor in charge of the imperial power also showed identification and recognition in dealing with the problems of Hui and Islam, and the monument with engraved imperial edict placed in the mosque was a symbol of imperial power, a tribute to allow the Hui and Islam to legally live in the dynasty, and also a clear sign of national identity.

Some magistrates, however, argued that the Hui ethnic community, which was of distinct religious and cultural symbol boundary, far beyond the scope of blood, clan and geographical areas, and of highly social organization, was completely a "different species" free from the law and decree. In addition, local officials could also be very good at outlining the stereotype image of the Hui as "different species", and these descriptions would put the Hui at an inferior and derogatory status, thus consciously completing the process to stigmatize Hui, which provide only one advantage to local officials, namely, offering political capital services to their regional stable governance. On the one hand, they could construct a significant symbolic boundary between the Han and Hui - the inner and outer group, and the outside group (the Hui) was kept at the low and despicable position, thus depriving the outer group's (the Hui's) access to social resources, opportunities and rights, by doing so, it would be conducive to the formation of a relatively positive self-image of the Han nationality, consolidate the social identity already formed by the main ethnic group, and ultimately served local governance. On the other hand, when the stereotype of the Hui was successfully constructed, their image would become ugly, rude, aggressive, lazy, as well as stupid, that is to say, the Hui people were dehumanized. In that case, no matter what kind of measures had been taken or were planned to take by magistrates against the Hui people, it would be deemed to be reasonable and was unquestioned, and this would also contribute to magistrates' local governance through simple methods.

Therefore, it can be said that the people of the Hui then could feel the ubiquitous rejection from the outside world, which could lead to the deprival of their legitimate rights and interests, welfare, and chance of living as an ordinary social member, and the Hui's mentality was suffering trauma and social identity was threatened. As a result, the Hui people would endeavor to maintain the existence of self-identity because it was an important source of self-esteem, meanwhile, they must consolidate and emphasize the legal status of their own ethnic groups in the country and society, only in this way can they share the deserved social resources and open up the upward channels in the community. So the Hui people consciously engraved the imperial edict issued by the emperor in favor of their own ethnic group on stone and put it in the mosque. The imperial edict was different from any ordinary people's speech because it was the emperor's message, opinion, attitude, and also a symbol of the emperor. Therefore, the application of imperial edict by the Hui people indicates their identity to the emperor, to the imperial power, as well as to the country. With the imperial authority, the Hui would endow their own religious beliefs and social status with legitimacy and rationality by using the imperial edict.

Imperial edict monument became a bond of connection that linked the country's mainstream culture with the sub-culture of the Hui ethnic group; it linked the recognition of the state and the 
response of the Hui ethnic group; and it also connected the Hui's national identity and self-identity. When the Hui people lost the right to explain their own ethnic group, religious belief and traditional culture, they could only use the imperial power and the imperial edict to complete the construction of its orthodoxy and annotation, and redefine the social status of the overall Hui nationality. It can be said that the imperial edict monument in mosque indeed became a thought-provoking cultural phenomenon.

\section{Part 3}

The Hui people living in the feudal dynasty were the subjects under the control of the monarch, being loyal to the King and obedient to imperial power was the only feasible path for them to stick to their faith and maintain the sub-culture and minor tradition in the heterogeneous cultural environment, otherwise, they would suffer control, suppression and elimination. The continuation of ethnic group depended on the construction and reconstruction of ethnic identity, while the existence and development of ethnic identity depended on the attribution and confirmation to the imperial power, the imperial court, as well as the country. Therefore, we can agree that the Hui nationality since Ming dynasty and Qing dynasty, even the Hui's ancestors in Tang dynasty, Song dynasty, and Yuan dynasty, consistently jousted with the process of recognition and confirmation of imperial clan about the Hui group. They revered the imperial power in exchange for their survival under imperial permission, and constructed their own ethnic identity by using the social resources conferred by the imperial power. That is to say, the relationship between the Hui's dynasty identity and ethnic identity was established. On the one hand, dynasty identity became a prerequisite and basic guarantee for the existence of ethnic identity; on the other hand, ethnic identity provided basic elements and emotional foundation for the construction and consolidation of the dynasty identity. After the revolution of 1911, an important historical task for China, compared with the traditional monarchy, was to change from the imperial dynasty to modern country where there was no longer any "subjects" or "people" who had personal attachment to the dynasty, but a completely independent "citizen" according to the law. During this process, people of all ethnic groups in China, including the Hui, became citizens who were structured and organized by the law, and state power was their "source of structural dominance", then people would reproduce national identity in order to complete the rationalization of "source of structural dominance". Besides, in the period of the Republic of China, the Hui elites searched for all kinds of cultural materials in a very similar but indeed different historical situation, and one of their aims was to redefine the social status of the overall Hui nationality and to seek the comprehensive transformation of the Hui society, for this reason, they would reformulate the ethnic identity so as to provide spiritual power for the realization of the above vision.

From the late Qing dynasty to the early Republic of China, Chinese people, including the Hui, completed the transformation from subjects to citizens, the "Republic of China" which was originated from “the great Qing dynasty” let people's loyalty to the feudal dynasty convert to identity about modern state, moreover, the original ethnic identity of ordinary people was also clearly defined as the national identity along with the popularization of modern national concept. In this historical context, the group identity and dynasty identity of the Hui nationality in feudal dynasty gradually changed into ethnic identity and national identity, yet for all that, the past ethnic group of Hui nationality - the inner structure of the dynasty identity paradigm didn't changed but was passed down in the way of cultural gene inheritance, therefore, there was still a strong internal connection and interaction between the Hui's ethnic identity and national identity.

\section{Acknowledgments}

This paper is the phasic research findings of Theoretical and Practical Research on the Construction of the Common Spiritual Home of All Ethnic Groups, a National Social Science Foundation Project in 2015. The project number is: $15 A M Z 001$ 


\section{References}

[1] Zhang Zhongfu. The Hui Incident in Northwest of Qing Dynasty - Reflections on Social and Cultural adaptation and National Identity, United Publishing Company (Taiwan), 2001.

[2] Fang Wen. Discipline System and Social Identity, Press of Renmin University of China, 2008: 170.

[3] Haug. Social Identity Process, Press of Renmin University of China, 2011: 96.

[4] Manuel Custer. The power of identification, Social Science Literature Press, 2006: 5. 